\title{
Zoospore Chemotaxis in the Rumen Phycomycete Neocallimastix frontalis
}

\author{
By COLIN G. ORPIN AND LYNNE BOUNTIFF \\ Department of Biochemistry, Agricultural Research Council, \\ Institute of Animal Physiology, Babraham, Cambridge CB2 $4 A T$
}

(Received 30 August 1977)

\begin{abstract}
Neocallimastix frontalis zoospores showed chemotaxis to a range of carbohydrates, but not to the common amino acids, purines, pyrimidines or vitamins. Four chemoreceptors were identified: the glucose receptor, sensitive to D-glucose, D-galactose, D-xylose, L-sorbose, D-fucose and 2-deoxy-D-glucose; the sucrose receptor, sensitive to sucrose, D-fructose and raffinose; the mannose receptor, sensitive to D-mannose and D-glucose; and the sorbitol receptor, sensitive to D-sorbitol and D-mannitol. Growth of the vegetative stage of $N$. frontalis did not occur with D-xylose, L-sorbose, D-fucose, 2-deoxy-D-glucose, raffinose, D-mannose or D-sorbitol. The zoospores were attracted to carbohydrate mixtures representing the soluble carbohydrates found in different barley tissues; the highest response was with those mixtures representing carbohydrates of awn and inflorescence tissue. Chemotaxis also occurred preferentially to the awn and inflorescence tissue carbohydrate combinations rather than to carbohydrate combinations representing other tissues. Germination of the zoospores occurred in medium containing glucose in excess of $\mathrm{IO}^{-4} \mathrm{M}$.
\end{abstract}

\section{INTRODUCTION}

The flagellated zoospores of the rumen phycomycete fungus Neocallimastix frontalis are released from sporangia borne on the vegetative stage of the organism soon after the host animal eats (Orpin, 1975). The zoospores may invade, germinate upon and grow at the expense of plant tissue present in the rumen (Orpin, 1977). Not all plant tissues are invaded by the zoospores to the same extent; a marked preference is shown for inflorescence tissue where the zoospores germinate principally at the stomata and on damaged areas. Growth of the single rhizoid results in penetration of the plant tissue through the stoma or damaged epidermis. Because of the marked substratum selection shown by the zoospores and their germination at the stomata, chemotaxis was thought likely to be operative. Some phycomycete zoospores show positive chemotaxis to L-leucine and L-lysine [Allomyces macrocygnus and $A$. arbuscula (Machlis, 1969)] and to carbohydrates [Pythium aphanidermatum (Royle \& Hickman, 1964)].

The chemotactic response of $N$. frontalis zoospores with a range of carbohydrates, amino acids, purines, pyrimidines and vitamins has now been examined. On the basis of these results, a mechanism is suggested for the preferential attraction of the zoospores to inflorescence tissues of grasses in the rumen.

\section{METHODS}

Animals. Sheep, Clun Forest wethers, each fitted with a permanent rumen cannula, were fed I kg hay chaff and $100 \mathrm{~g}$ rolled oats daily.

Preparation of rumen fluid and zoospore suspensions in fresh rumen fluid. Centrifuged rumen fluid and sterile reduced rumen fluid supernatant were prepared according to Orpin (1977). Rumen fluid, used as a 
source of neocallimastix zoospores, was aspirated 17 to $23 \mathrm{~h}$ after the sheep was fed, filtered through a layer of muslin and $40 \mathrm{ml}$ filtrate was centrifuged for $10 \mathrm{~min}$ at room temperature at $1500 \mathrm{~g}$. The pellet was resuspended in $15 \mathrm{ml}$ supernatant fluid and incubated at $39^{\circ} \mathrm{C}$ for $0.5 \mathrm{~h}$ with 'inducer' (Orpin, 1975) extracted from $5.0 \mathrm{~g}$ dry wt oats. This resulted in the release of $N$. frontalis zoospores from the sporangia. The suspension was used for some chemotaxis experiments.

Culture in vitro. Stock cultures of $N$. frontalis were grown using the methods of Orpin (I975). The organism was also grown in liquid medium consisting of ( $\mathrm{g} \mathrm{I}^{-1}$, except where stated): yeast extract, 10.0; tryptone, 20.0; L-cysteine hydrochloride, I.0; glucose, I.0; $\alpha$-linolenic acid, 0.05; streptomycin, $0 . \mathrm{I}$; sodium benzyl penicillin, $10^{5}$ i.u. $\%$; and centrifuged rumen fluid, I0 \% (v/v). The medium constituents, except the antibiotics, were autoclaved in $99 \%$ of the final volume, allowed to cool, and the antibiotics (in sterile distilled water, $\mathrm{I} \%$ of final medium volume) were added aseptically. The medium was dispensed in $8 \mathrm{ml}$ quantities into $\mathrm{I} 25 \times 13 \mathrm{~mm}$ rimless test-tubes inoculated with organisms from a thriving stock culture $(0.5 \mathrm{ml})$ and incubated at $39^{\circ} \mathrm{C}$ under $\mathrm{CO}_{2}$; the cultures were passaged every 2 days. Suspensions of zoospores were prepared by filtering the cultures $(100 \mathrm{ml})$ through a $10 \mathrm{~mm}$ pad of cotton-wool placed in the stem of a $50 \mathrm{~mm}$ diam. glass funnel, and centrifuging the filtrate containing the zoospores (but no vegetative growth) at $1000 \mathrm{~g}$ for $5 \mathrm{~min}$ at room temperature. The pellet was washed by centrifuging in reduced centrifuged rumen fluid (IO $\mathrm{ml}$ ) and finally suspended in reduced centrifuged rumen fluid to a zoospore density of approximately $10^{4} \mathrm{ml}^{-1}$. These suspensions were used throughout except when chemotaxis was determined in fresh filtered rumen fluid.

Chemotaxis experiments. Chemotaxis experiments using suspensions of zoospores grown in vitro were performed in chambers similar to that of Palleroni (1976), using $0.9 \mathrm{ml}$ of spore suspension in the chambers. The compound being assayed was dissolved in $\mathrm{CO}_{2}$-saturated sterile reduced centrifuged rumen fluid, and the solution was taken up in $50 \mu \mathrm{l}$ Drummond microcap capillaries (Drummond Scientific Co., U.S.A.) which were then placed in the chemotaxis chambers. After $30 \mathrm{~min}$ incubation at $39^{\circ} \mathrm{C}$ each capillary was removed, washed externally (Palleroni, I976) with sterile reduced rumen fluid, and the contents were expressed on to a microscope slide. The number of neocallimastix zoospores was determined microscopically.

Experiments with zoospore suspensions in fresh rumen fluid were performed in chambers similar to that designed by Adler (1973) using $20 \mu \mathrm{l}$ Drummond microcap capillaries. One end of the capillary was sealed with latex, the other was inserted into the rumen fluid preparation $(0.2 \mathrm{ml})$. Incubation and counting were performed as described for the Palleroni (1976) chamber.

For experiments with organisms cultured in vitro, the same reduced centrifuged rumen fluid was used both for suspending the zoospores and for the attractant solution. For experiments with fresh rumen fluid, attractants were dissolved in reduced centrifuged rumen fluid taken from the same sheep $24 \mathrm{~h}$ previously.

The $\mathrm{pH}$ of reduced centrifuged rumen fluid used in the $\mathrm{pH}$ experiments was adjusted as required with $\mathrm{ro} \%$ $(\mathrm{w} / \mathrm{v}) \mathrm{NaHCO}_{3} \cdot \mathrm{IOH}_{2} \mathrm{O}$ or acetic acid with $\mathrm{CO}_{2}$ flowing through the medium (acetate did not affect chemotaxis).

Optical configuration of carbohydrates and amino acids. Unless otherwise specified, carbohydrates (where appropriate) were of the D-configuration, and amino acids the L-configuration.

Determination of specificity and number of chemoreceptors. One attractant at its optimum concentration was put in the capillary tube, and the other, at $0.0 \mathrm{I}$, was put in both the capillary tube and the suspension of zoospores. The reciprocal experiments were also performed. In each case the attractant was dissolved in reduced centrifuged rumen fluid, and equilibrated with $\mathrm{CO}_{2}$.

Determinations. Sucrose was determined enzymically using the method of Bergmeyer \& Klotzsch (1963), fructose by the method of Klotzsch \& Bergmeyer (1963) and glucose by that of Dahlqvist (196I).

Plants. Barley (Hordeum distichon) plants were kindly supplied by Dr A. A. Jenkins, Agricultural Research Council, Plant Breeding Institute, Trumpington, Cambridge. Seven days after anthesis the plants were harvested and dissected into roots, stem, leaves (including ligules), awns and the remaining inflorescence tissue. Yellowing leaves were discarded. Soil was removed from the roots by washing them gently with $0.9 \%$ $(\mathrm{w} / \mathrm{v}) \mathrm{NaCl}$. The separate tissues were homogenized in distilled water [100 $\mathrm{ml}$ (g dry wt tissue $)^{-1}$ ] using an Ultra-turrax homogenizer, filtered, and the filtrates were heated at $100{ }^{\circ} \mathrm{C}$ for 5 min to destroy enzymic activity. The filtrates were centrifuged at $38000 \mathrm{~g}$ for $\mathrm{I} \mathrm{h}$, and the supernatants were assayed for glucose, sucrose and fructose.

Removal of soluble materials from barley awns. No method could be devised that would specifically remove soluble carbohydrates from plant tissues without also removing other soluble compounds. Two compromise methods were used, each starting with O.I g dry wt awns: (i) the awns were submerged in distilled water (I 1), stirred for $48 \mathrm{~h}$ at $4{ }^{\circ} \mathrm{C}$, removed and washed with distilled water; (ii) the awns were incubated in a nylon bag in the rumen of a sheep devoid of phycomycete fungi (Orpin, 1977) for $24 \mathrm{~h}$, removed and washed with distilled water. Awns prepared by these methods were then incubated in nylon bags in a rumen containing $N$. frontalis as the sole phycomycete (Orpin, 1977); the bags were removed after $19 \mathrm{~h}$ and the invasion of the 
tissue was assessed using the methods of Orpin (1977). Sucrose, glucose and fructose present in the tissues after treatment to remove soluble compounds were determined as described above.

Germination experiments. Zoospore suspensions $\left(10^{4}\right.$ spores $\left.\mathrm{ml}^{-1}\right)$ in chemotaxis medium containing glucose at between $10^{-7}$ and $\mathrm{I} M$ were incubated under $\mathrm{CO}_{2}$ at $39^{\circ} \mathrm{C}$. Samples were taken every $5 \mathrm{~min}$ for the first $30 \mathrm{~min}$, at $15 \mathrm{~min}$ intervals until $2.5 \mathrm{~h}$, and then hourly up to $4.5 \mathrm{~h}$. The proportion of zoospores which had germinated in each sample was determined by microscopy, and plotted against time. The graph was extrapolated to determine the time for $100 \%$ germination if this had not been reached during the experiment.

\section{RESULTS}

If $N$. frontalis were attracted to plant tissue by materials diffusing into the rumen fluid, no invasion of tissues devoid of soluble materials should occur. The degree of invasion of barley awns, treated to remove all soluble materials, was assessed. Untreated awns, after incubation in the rumen for $\mathrm{I} 9 \mathrm{~h}$ followed by exposure to the inducer of zoosporogenesis, released $\mathrm{I} \cdot \mathrm{I} \times \mathrm{IO}^{7}$ zoospores ( $\mathrm{g}$ dry wt tissue) ${ }^{-1}$; awns treated by prior incubation in a rumen devoid of phycomycetes released $3 \cdot I \times 10^{4}$ zoospores ( $g$ dry wt tissue) $)^{-1}$ and those leached with distilled water released $14.4 \times 10^{4}$ zoospores (g dry wt tissue) $)^{-1}$. This suggested that soluble diffusible materials in the plant tissue were acting as chemotactic agents. The capacity of carbohydrates, amino acids, purines, pyrimidines and vitamins (all likely to be present in plant tissues, though many only at low concentrations) to elicit chemotaxis by the zoospores was then examined.

As preliminary experiments showed that $N$. frontalis zoospores were attracted to glucose; glucose at $10^{-3} \mathrm{M}$ was used to determine the optimum conditions (temperature, $\mathrm{pH}$, cell density, reproducibility) for chemotaxis, using cells grown in vitro.

Rate of accumulation of zoospores in capillaries. The number of zoospores which entered capillaries not containing attractant was small in comparison with the number present and with the number entering the capillary containing $\mathrm{IO}^{-3} \mathrm{M}$-glucose. This background accumulation never exceeded $0.3 \%$ of the total zoospores and was presumably due to random swimming of the zoospores. The rate of accumulation of cells into capillaries containing $\mathrm{IO}^{-3} \mathrm{M}$-glucose was initially slow but increased after $5 \mathrm{~min}$ to reach a constant maximum rate between 5 and $30 \mathrm{~min}$ (Fig. I). The rate then decreased markedly. The time at which this point was reached varied with the glucose concentration but it was always within $\mathrm{i} h$.

At low zoospore densities, the rate of accumulation in capillaries was proportional to density; at densities in excess of $5 \times 10^{3} \mathrm{ml}^{-1}$, increasing the zoospore density had no significant effect on the number of spores entering the capillary (Fig. 2). All subsequent experiments were performed using a zoospore density of $10^{4} \mathrm{ml}^{-1}$ to minimize the effect of density on the rate of accumulation in the capillary.

Reproducibility. When 20 capillary tubes, containing $10^{-3} \mathrm{M}$-glucose, were incubated with zoospore suspensions for $\mathrm{I} h$ at $39{ }^{\circ} \mathrm{C}, 6 \cdot 2 \pm 0 \cdot 8 \times \mathrm{IO}^{3}$ spores accumulated.

Effect of temperature and $\mathrm{pH}$. Chemotaxis to $1 \mathrm{O}^{-3} \mathrm{M}$-glucose was markedly affected by temperature, the optimum being $40 \pm 2{ }^{\circ} \mathrm{C}$. Outside these limits chemotaxis decreased rapidly; no chemotaxis was recorded at 50 or $36^{\circ} \mathrm{C}$ (Fig. 3). Chemotaxis to $\mathrm{IO}^{-3} \mathrm{M}$-glucose was independent of $\mathrm{pH}$ in the range 5.5 to 7.0 but outside this range taxis decreased (Fig. 3 ). All subsequent experiments were performed at $\mathrm{pH} 6 \cdot 5$ to 7.0 at $39^{\circ} \mathrm{C}$.

Effect of soluble protein. Plant fraction I protein (ribulose-I,5-bisphosphate carboxylyase) is the major protein released from plant tissue by mastication of food by the host animal (Reid, Lyttleton \& Mangan, 1962) and the concentration of the soluble protein in the bolus may attain $100 \mu \mathrm{g} \mathrm{ml}^{-1}$. Because of this, and because $N$. frontalis zoospores are most abundant in the rumen in the first hour after the host animal has commenced feeding (Orpin, I975), i.e. when soluble protein will be at its highest concentration, the effect of fraction $\mathrm{I}$ protein $\left(\mathrm{I} 00 \mu \mathrm{g} \mathrm{ml}^{-1}\right.$ ) on chemotaxis was investigated. No taxis to fraction I protein was recorded and it neither stimulated nor inhibited taxis to $1 \mathrm{O}^{-3} \mathrm{M}$-glucose.

Chemotaxis to different carbohydrates. A range of carbohydrates at $10^{-3} \mathrm{M}$ or $0.0 \mathrm{I} \%$ 


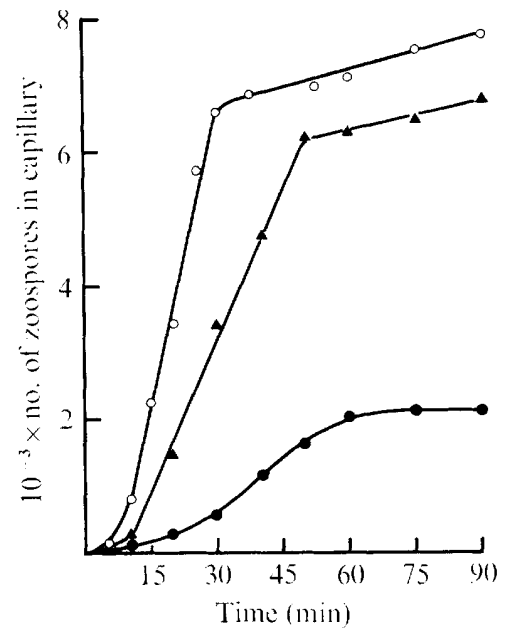

Fig. I

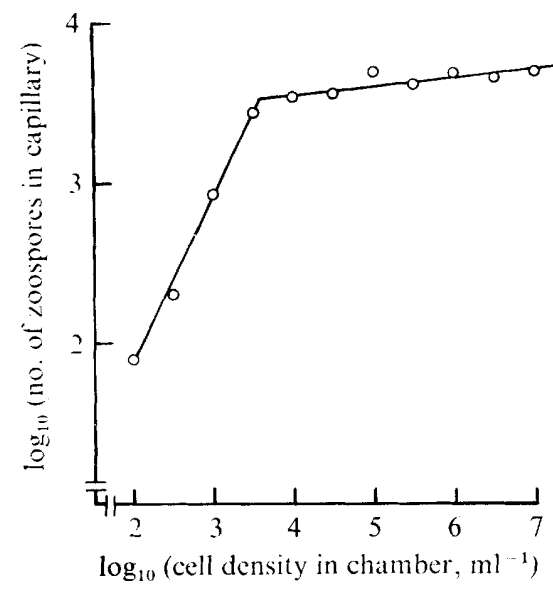

Fig. 2

Fig. 1. Accumulation of $N$. frontalis zoospores in capillaries containing different concentrations of glucose: $\bigcirc, 10^{-3} \mathrm{M} ; \boldsymbol{\Lambda}, 10^{-4} \mathrm{M} ; \boldsymbol{O}, \mathrm{IO}^{-5} \mathrm{M}$. The chemotaxis chambers each contained $0.9 \mathrm{ml}$ of zoospore suspension $\left(\mathrm{IO}^{4}\right.$ spores $\mathrm{ml}^{-1}$ ) and were incubated at $39^{\circ} \mathrm{C}$. At intervals, the zoospores which had accumulated in the capillaries were counted. Results are corrected for random entry by the zoospores. Average of three experiments.

Fig. 2. Effect of zoospore density on accumulation in capillaries. The chemotaxis chambers each contained $0.9 \mathrm{ml}$ of zoospore suspension containing between $10^{2}$ and $10^{7}$ spores $\mathrm{ml}^{-1}$. The chambers were incubated at $39^{\circ} \mathrm{C}$ for $30 \mathrm{~min}$ and the zoospores which had accumulated in capilaries containing $\mathrm{IO}^{-3} \mathrm{M}$-glucose were counted. Results are corrected for random entry by the zoospores. Average of three experiments.

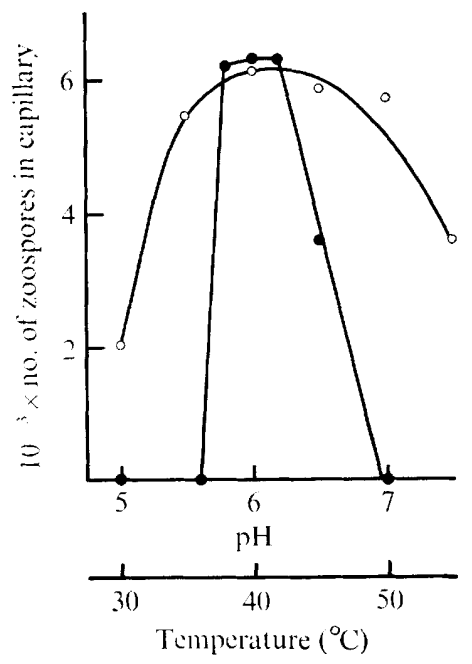

Fig. 3

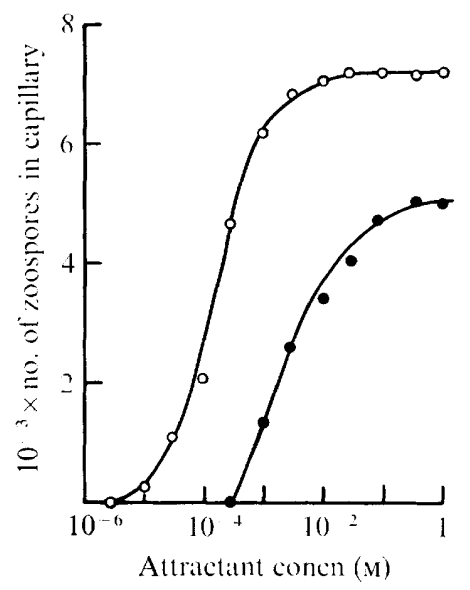

Fig. 4

Fig. 3. The effects of temperature $(O)$ at $\mathrm{pH} 6.5$ and $\mathrm{pH}(\mathrm{O})$ at $39{ }^{\circ} \mathrm{C}$ on chemotaxis by $N$. frontalis zoospores. The chambers each contained $0.9 \mathrm{ml}$ of zoospore suspension $\left(\mathrm{IO}^{4}\right.$ spores $\left.\mathrm{ml}^{-1}\right)$ containing $\mathrm{IO}^{-3} \mathrm{M}$-glucose as attractant. In each experiment incubation was for $30 \mathrm{~min}$. Results are corrected for random entry by zoospores. Average of two experiments.

Fig. 4. Concentration-response curves for chemotaxis by $N$. frontalis zoospores to glucose $(O)$ and mannose $(\Theta)$. The chambers each contained $0.9 \mathrm{ml}$ of zoospore suspension $\left(\mathrm{IO}^{4}\right.$ spores $\left.\mathrm{ml}^{-1}\right)$ and were incubated at $39^{\circ} \mathrm{C}$ for $30 \mathrm{~min}$. Results are corrected for random entry by zoospores. Average of two experiments. 
Table I. Threshold and optimum concentrations for taxis to different carbohydrates and use of these carbohydrates for growth by N. frontalis

The threshold concentration is the minimum concentration tested which elicited chemotaxis. The optimum concentration is that which attracted the most zoospores per unit time. Columns (I) refer to washed suspensions of $N$. frontalis zoospores cultured in vitro; columns (2) refer to suspensions of zoospores in fresh filtered rumen fluid. Growth is recorded as: - , no growth; $(+)$, poor growth; + , good growth.

\begin{tabular}{|c|c|c|c|c|c|}
\hline \multirow[b]{2}{*}{ Compound } & \multicolumn{2}{|c|}{ Threshold concn $(\mathrm{M})$} & \multicolumn{2}{|c|}{ Optimum concn $(\mathbf{M})$} & \multirow[b]{2}{*}{ Growth } \\
\hline & (I) & (2) & (I) & (2) & \\
\hline Xylose & $10^{-5}$ & $5 \times 10^{-4}$ & $>5 \times 10^{-1}$ & $10^{-1}$ & - \\
\hline Fructose & $5 \times 10^{-6}$ & $10^{-5}$ & $10^{-1}$ & $\mathrm{IO}^{-1}$ & + \\
\hline Glucose & $5 \times 10^{-6}$ & $\mathrm{IO}^{-5}$ & $>10^{-2}$ & $5 \times 10^{-2}$ & + \\
\hline Galactose & $10^{-4}$ & $5 \times 10^{-3}$ & $5 \times 10^{-2}$ & $5 \times 10^{-1}$ & + \\
\hline Mannose & $5 \times 10^{-4}$ & $5 \times 10^{-4}$ & $>5 \times 10^{-1}$ & $10^{-1}$ & - \\
\hline Sorbose & $5 \times 10^{-4}$ & $10^{-3}$ & $10^{-3}$ & $5 \times 10^{-2}$ & - \\
\hline Sucrose & $10^{-7}$ & $5 \times 10^{-4}$ & $5 \times 10^{-2}$ & $10^{-1}$ & + \\
\hline Raffinose & $5 \times 10^{-3}$ & $10^{-2}$ & $10^{-2}$ & $5 \times 10^{-1}$ & - \\
\hline Sorbitol & $5 \times 10^{-4}$ & $5 \times 10^{-3}$ & $5 \times 10^{-1}$ & IO $0^{-1}$ & - \\
\hline Mannitol & $5 \times 10^{-3}$ & $10^{-3}$ & $10^{-1}$ & $10^{-1}$ & $(+)$ \\
\hline Fucose & $10^{-4}$ & ND & $10^{-2}$ & ND & - \\
\hline 2-Deoxy-D-glucose & $10^{-5}$ & ND & $5 \times 10^{-2}$ & $10^{-1}$ & - \\
\hline
\end{tabular}

ND, Not determined.

(polysaccharides) were tested for their ability to elicit chemotaxis. Zoospores, produced from vegetative growth grown on glucose as the major energy and carbon source, moved towards glucose, galactose, xylose, fructose, mannose, L-sorbose, sucrose, raffinose, mannitol, sorbitol, fucose and 2-deoxy-D-glucose (Table I). A concentration-response curve was plotted for each attractant (see Fig. 4 for response to glucose and mannose) and the optimum concentration for chemotaxis and the threshold concentration (the lowest concentration of attractant at which a response was first detected) were derived (Table $\mathrm{I}$ ). The following compounds at $\mathrm{IO}^{-3} \mathrm{M}$ did not elicit chemotaxis: erythrose, L-arabinose, ribose, L-rhamnose, cellobiose, maltose, trehalose, melibiose, melezitose, aesculin, salicin, adonitol and dulcitol; nor did the following at $0.0 \mathrm{I} \%(\mathrm{w} / \mathrm{v})$ : rice starch, soluble starch, cellulose (Sigmacel MN30), glycogen, dextrin and pectin.

Experiments with fresh rumen fluid. Since conditions in the rumen are different from those we had used in vitro, we repeated the experiments using $N$. frontalis zoospores suspended in fresh filtered rumen fluid after induction of zoosporogenesis in vitro. We found that zoospores responded to the same range of carbohydrates but the threshold values and optimum concentrations of the attractants were both higher (Table I). To ascertain if the zoospores responded to the products of fermentation of carbohydrates produced by other rumen micro-organisms, we tested acetate, propionate, $n$-butyrate, 2 -methylpropionate, lactate and succinate separately at $\mathrm{IO}^{-3} \mathrm{M}$; none attracted the zoospores.

Amino acids, purines, pyrimidines and vitamins. Since $N$. frontalis zoospores were attracted by soluble compound(s) diffusing from the plant tissue, taxis to the common amino acids, purines, pyrimidines and vitamins, which may occur free in plant tissues at low concentrations, was investigated. No taxis to any of these compounds was detected. The amino acids tested $\left(\right.$ at $\left.\mathrm{IO}^{-4} \mathrm{M}\right)$ were: glycine, alanine, serine, threonine, valine, leucine, isoleucine, phenylalanine, tyrosine, methionine, tryptophan, proline, histidine, aspartate, glutamate, arginine, lysine and asparagine. The nucleotide bases tested (at $10^{-4} \mathrm{M}$ ) were: adenine, guanine, cytosine, and thymine. The vitamins tested (at $\left.\mathrm{IO}^{-5} \mathrm{M}\right)$ were: $\alpha$-tocopherol, ascorbate, thiamin, riboflavin, nicotinamide, pyridoxal phosphate, pantothenate, biotin, folic acid, inositol and cyanocobalamin. 
Chemotaxis to carbohydrates in the presence of a second attractant. To ascertain how many chemoreceptor sites were present on zoospores and to determine their specificity, an attractant, at its optimum concentration, was put in the capillary and a second attractant, at $0 . \mathrm{OI} \mathrm{M}$, was put in both the zoospore suspension and the capillary to saturate the receptor sites for that compound. If the two attractants use the same receptor no taxis should occur (Adler, 1969). If not, taxis should not be inhibited. The results (Table 2) suggest that there are separate receptors for glucose, sucrose, mannose and sorbitol. The glucose receptor was sensitive to glucose, galactose, xylose, L-sorbose, fucose and 2-deoxy-D-glucose; the sucrose receptor to sucrose, fructose and raffinose; the mannose receptor to mannose and glucose; and the sorbitol receptor to sorbitol and mannitol.

Metabolism of carbohydrates. Neocallimastix frontalis failed to grow in liquid medium on

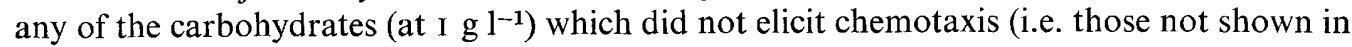
Table I). Growth did occur on many, but not all, of the carbohydrates eliciting chemotaxis (Table I); the exceptions were xylose, mannose, L-sorbose, raffinose, sorbitol, fucose and 2-deoxy-D-glucose. It is not surprising that fucose and 2-deoxy-D-glucose, which are analogues of galactose and D-glucose respectively and can inhibit galactose and glucose metabolism, were not utilized as carbon sources. Mannose and sorbitol both elicited taxis and may be utilized by other rumen micro-organisms (Hungate, I966) but neither was utilized by $N$. frontalis.

Distribution of sucrose, fructose and glucose in tissues of barley. Sucrose, glucose and fructose are the major soluble carbohydrates present in grass tissues (Bailey, 1964), so their levels in the different barley tissues were determined (Table 3). The highest concentrations of sucrose fructose and glucose were in the awns and inflorescence tissue. All three sugars were detected in all the tissues except the roots which were devoid of sucrose.

Taxis to multiple attractants. Sucrose, glucose and fructose, the abundant carbohydrates of barley tissues, were examined in various combinations (Table 4 ). Their effects were synergistic for chemotaxis at low concentrations, but at high concentrations this effect decreased (Table 4). When sucrose, glucose and fructose were added together in the proportions found in the different barley tissues (cf. Table 3), their capacity to attract the zoospores was strongest with mixtures representing awns and inflorescence tissue (Table 5). In addition, if the zoospores were exposed to two capillaries containing the carbohydrate mixtures representing two different types of tissue, taxis was shown principally to that containing the inflorescence or awn tissue carbohydrates (Table 6).

Germination of zoospores in the presence of glucose. Glucose, at $0.08 \mathrm{M}$, stimulated the encystment and germination within $30 \mathrm{~min}$ of all the zoospores attracted to capillaries. As smaller numbers of germinated cells occurred in capillaries containing less glucose, the time required for zoospores to germinate in chemotaxis medium containing different glucose concentrations was investigated. The results (Fig. 5) show that complete germination occurs at glucose concentrations of $0.00 \mathrm{I}$ to $0.5 \mathrm{M}$. Germination at the lowest glucose concentration took $6 \mathrm{~h}$.

\section{DISCUSSION}

Little information on chemotaxis of phycomycete zoospores to specific attractants is available. Royle \& Hickman (I964) showed that the zoospores of Pythium aphanidermatum were attracted to a mixture of $\mathrm{I} \cdot 83 \times 10^{-2} \mathrm{M}$-glucose and -fructose and $0.97 \times 10^{-2} \mathrm{M}$-sucrose in $\mathrm{I} \%$ casein hydrolysate. These levels of carbohydrates were much higher than the concentrations of the same carbohydrates eliciting chemotaxis in $N$. frontalis zoospores. Chet \& Mitchell (1976) concluded that phycomycete zoospores were much less sensitive to low concentrations of attractants than were bacteria, but we have found $N$. frontalis zoospores to be nearly as sensitive to glucose (threshold $5 \times 10^{-6} \mathrm{M}$ ) and more sensitive to fructose (threshold $5 \times \mathrm{IO}^{-6} \mathrm{M}$ ) than Escherichia coli which has thresholds of $3 \times 1 \mathrm{IO}^{-6} \mathrm{M}$ and $\mathrm{I} \times \mathrm{IO}^{-5} \mathrm{M}$ respectively for these sugars (Adler, 1975). The threshold concentrations for $N$. frontalis 


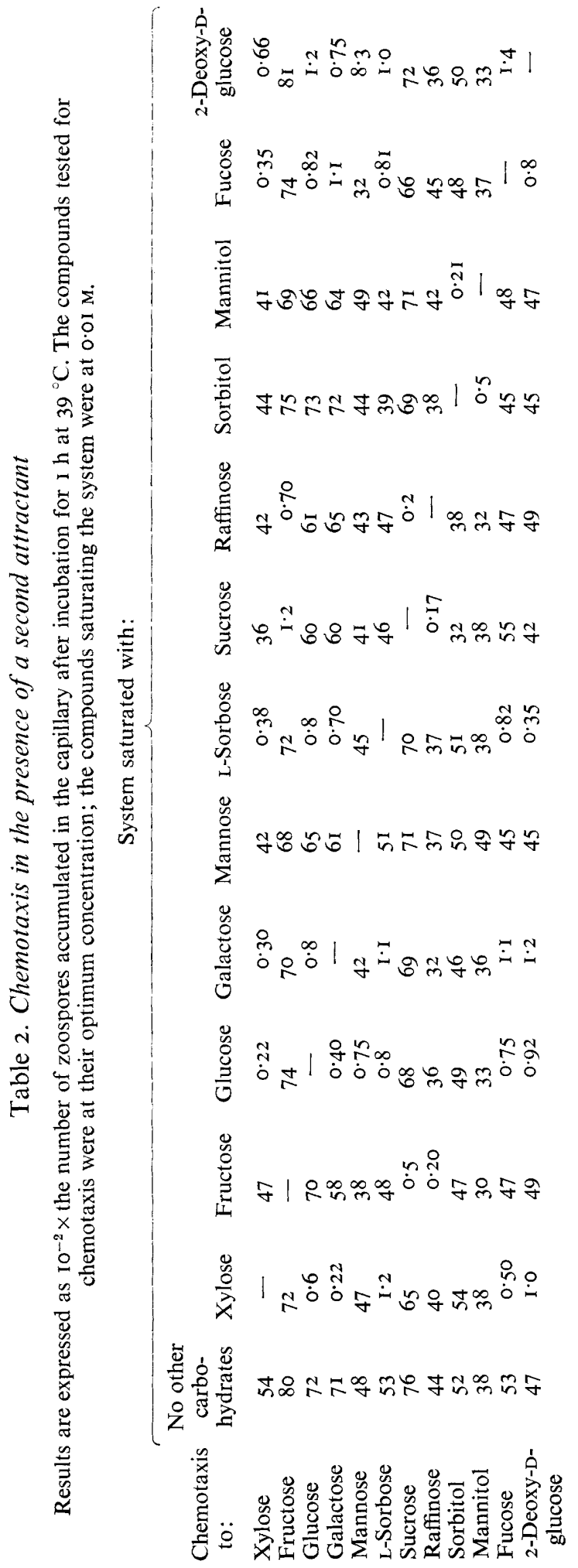


Table 3. Sucrose, glucose and fructose concentrations $(\%$ dry wt) in different tissues of barley

$\begin{array}{lccc}\text { Tissue } & \text { Sucrose } & \text { Glucose } & \text { Fructose } \\ \text { Awns } & 10 \cdot 8 & 4 \cdot 7 & \mathrm{I} \cdot 8 \\ \text { Inflorescence } & 9 \cdot 5 & 4 \cdot 7 & \mathrm{I} \cdot 9 \\ \text { Leaves } & 4 \cdot 3 & 1 \cdot 4 & 0 \cdot 8 \\ \text { Stem } & \mathrm{I} \cdot 7 & 0.4 & 0.5 \\ \text { Roots } & 0 & 0.6 & 0.4\end{array}$

Table 4. Effect of combinations of glucose, sucrose and fructose on chemotaxis by $N$. frontalis zoospores

Results show an average of two experiments, corrected for random entry of zoospores. In the carbohydrate mixtures, each component was at the concentration shown in the first column.

\begin{tabular}{cccccccc}
$\begin{array}{c}\text { Concn } \\
\text { of each } \\
\text { component }\end{array}$ & \multicolumn{7}{c}{$\begin{array}{c}\text { Rate of attraction of zoospores (spores } \text { min }^{-1} \text { ) } \\
\text { to carbohydrate mixtures containing: }\end{array}$} \\
$\begin{array}{cccccccc}\text { (M) } \\
10^{-5}\end{array}$ & $\mathrm{G}$ & $\mathrm{S}$ & $\mathrm{F}$ & $\mathrm{G}+\mathrm{S}$ & $\mathrm{F}+\mathrm{S}$ & $\mathrm{G}+\mathrm{F}$ & $\mathrm{G}+\mathrm{F}+\mathrm{S}$ \\
$2 \times 10^{-5}$ & 120 & 210 & 117 & 235 & 212 & 242 & 240 \\
$10^{-6}$ & $15 \cdot 2$ & 108 & 110 & 226 & 227 & 244 & $\mathrm{NT}$ \\
$10^{-7}$ & 0 & 5.6 & 0 & 216 & 207 & 233 & 246 \\
& & & 0 & 16.0 & $11 \cdot 0$ & 14.6 & 18.0
\end{tabular}

G, Glucose; F, fructose; S, sucrose. NT, Not tested.

\section{Table 5. Taxis of $N$. frontalis zoospores to soluble carbohydrate mixtures representing those found in different tissues of barley}

Compositions of soluble carbohydrate mixtures were calculated from the known soluble carbohydrate composition of each tissue, converted to a wet wt basis. The rate of attraction of zoospores was calculated from the number of spores present in the capillaries after Io min incubation at $39{ }^{\circ} \mathrm{C}$.

Composition of carbohydrate mixture (mM)

$\begin{array}{ccc}\text { Sucrose } & \text { Glucose } & \text { Fructose } \\ 40 \cdot 0 & 33 \cdot 0 & 12.5 \\ 35 \cdot 0 & 33 \cdot 0 & 13.0 \\ 16.0 & 10 \cdot 0 & 5.6 \\ 6.0 & 2 \cdot 7 & 3.4 \\ 0 & 4 \cdot 2 & 2 \cdot 7\end{array}$

Rate of zoospore

$\begin{array}{cc}\begin{array}{c}\text { Tissue } \\ \text { represented }\end{array} & \begin{array}{c}\text { attraction } \\ \text { (spores } \text { min }^{-1} \text { ) }\end{array} \\ \text { Awn } & 870 \\ \text { Inflorescence } & 820 \\ \text { Leaf } & 750 \\ \text { Stem } & 620 \\ \text { Root } & 430\end{array}$

Table 6. Attraction of N. frontalis zoospores to soluble carbohydrate mixtures representing two different types of tissues

Compositions of soluble carbohydrate mixtures were calculated from the known soluble carbohydrate composition of each tissue, converted to a wet wt basis. Two capillaries, each containing one of the mixtures under examination, were inserted into the same zoospore suspension $(0.9 \mathrm{ml})$ containing $10^{4}$ spores $\mathrm{ml}^{-1}$, and incubated for $30 \mathrm{~min}$ at $39^{\circ} \mathrm{C}$. The total numbers of zoospores entering each tube were determined by microscopy. Results are corrected for random entry of zoospores, and show the average of three experiments.

$\begin{array}{lccccc}\begin{array}{c}\text { Other tissue } \\ \text { carbohydrate }\end{array} & \begin{array}{c}\text { Percentage of total zoospores attracted } \\ \text { to carbohydrate mixture representing: }\end{array} \\ \text { mixture offered: } & \text { Inflorescence } & \text { Awn } & \text { Leaf } & \text { Stem } & \text { Roots } \\ \text { Inflorescence } & \text { ND } & 53 & \text { I } 8 & 8 & 3 \\ \text { Awn } & 47 & \text { ND } & 22 & \text { IO } & 5 \\ \text { Leaf } & 82 & 78 & \text { ND } & \text { ND } & \text { ND } \\ \text { Stem } & 92 & 90 & \text { ND } & \text { ND } & \text { ND } \\ \text { Roots } & 97 & 95 & \text { ND } & \text { ND } & \text { ND }\end{array}$

ND, Not determined. 


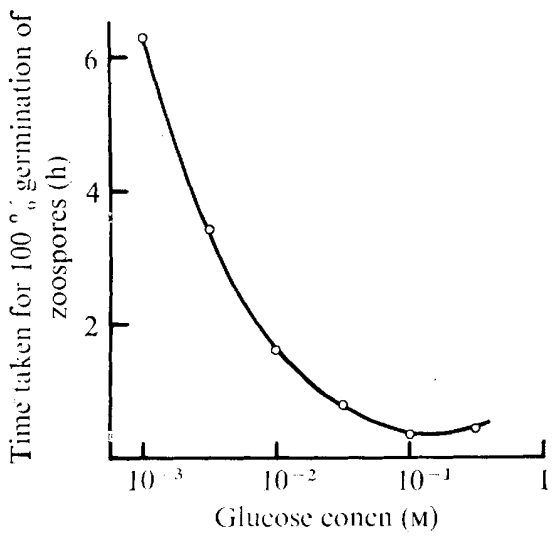

Fig. 5. Germination of zoospores of $N$. frontalis in the presence of glucose. Zoospores $\left(10^{4} \mathrm{ml}^{-1}\right)$ were incubated under $\mathrm{CO}_{2}$ in the chemotaxis medium containing different concentrations of glucose. The time for $100 \%$ germination was determined by plotting percentage germination against time, and extrapolating to $100 \%$ germination. Average of two experiments.

chemotaxis in the presence of fresh rumen fluid containing large numbers of bacteria were considerably higher than those in the absence of other organisms. Probably metabolism of the attractants occurs near to the orifice of the capillary, effectively decreasing the attractant concentration and reducing the zoospore chemotaxis. No doubt this situation also occurs near fresh plant particles in the rumen.

There are four different chemoreceptors in $N$. frontalis zoospores: for glucose, sucrose, sorbitol and mannose. Glucose and sucrose occur commonly in the diet of the host animal, and were readily metabolized by $N$. frontalis vegetative growth. The significance of the sorbitol receptor is difficult to understand since neither sorbitol nor mannitol, which used the same chemoreceptor, occur commonly in the diet of the host animal. The sorbitol receptor may be sensitive to other, as yet unidentified, dietary constituents. The mannose receptor was also sensitive to glucose. Since mannose occurs in the diet chiefly as mannan (Hungate, 1966) very little free mannose enters the rumen, and as mannose does not support the vegetative growth of $N$. frontalis, taxis to mannose probably does not occur in vivo. The mannose receptor may therefore be used for glucose taxis rather than mannose taxis. Other carbohydrates to which $N$. frontalis showed taxis, but which could not support the growth of the organism, are either not normally free in the diet (xylose, L-sorbose) or are usually absent (fucose, 2-deoxy-D-glucose).

The synergistic effect of glucose, fructose and sucrose at low concentrations, and preferential taxis to mixtures of soluble carbohydrates representing those found in awn and inflorescence tissue, is strong evidence that the soluble carbohydrates alone are responsible for the substratum selection by the zoospores. In addition, the glucose concentration in the awns $\left(3.3 \times 10^{-2} \mathrm{M}\right)$ was sufficient to trigger the germination of the zoospores. In the leaves of barley, the glucose present $\left(\mathrm{I} \cdot \mathrm{O} \times \mathrm{IO}^{-2} \mathrm{M}\right)$ would also be sufficient to trigger germination but taxis to the carbohydrates diffusing from the awn and inflorescence tissue would take precedence over those diffusing from the leaf tissue. In the absence of inflorescence tissue, invasion of and growth upon leaf tissue will probably occur, as $N$. frontalis grows vegetatively on several tissues when in the rumen (Orpin, 1975, 1977) and has been found in the rumen of a sheep on an inflorescence-free diet. The glucose content of leaves of perennial rye grass (Lolium perenne), a major dietary constituent in Great Britain, is approximately $0.8 \times 10^{-2} \mathrm{M}$ (Waite \& Boyd, 1953 ); this would also be sufficient to elicit chemotaxis and to trigger germination of the zoospores.

Taxis to, and growth in regions high in, soluble carbohydrates will enable the organism to 
grow in a microenvironment rich in other compounds such as proteins, amino acids, purines, pyrimidines and vitamins, which may also be required for growth. It may also allow the organism access to these compounds prior to, or at the same time as, their consumption by other rumen organisms.

Glucose, sucrose and fructose are depleted from the diet of sheep within 2 to $3 \mathrm{~h}$ of feeding (Phillipson \& McAnally, 1942). After this period N. frontalis zoospores would not be able to identify the inflorescence tissue by its soluble carbohydrate content. Since the zoospores are present in small numbers at any time of day in sheep fed once daily (Orpin, 1975), their subsequent germination may be delayed or may occur free in the rumen fluid. Germination under these conditions may be a function of time rather than substrate or substratum availability.

We thank Dr P. Kemp for cannulating the sheep. L. B. gratefully acknowledges the receipt of a bursary from the Agricultural Research Council.

\section{REFERENCES}

ADLER, J. (1969). Chemoreceptors in bacteria. Science I66, I 588-1 597.

ADLER, J. (I973). A method for measuring chemotaxis and use of the method to determine optimum conditions for chemotaxis in E. coli. Journal of General Microbiology 74, 77-91.

Adler, J. (1975). Chemotaxis in bacteria. Annual Review of Biochemistry 44, 341-356.

BaILey, R. W. (1964). Pasture quality and ruminant nutrition. I. Carbohydrate composition of ryegrass varieties grown as sheep pastures. New Zealand Journal of Agricultural Research 7, 496507.

Bergmeyer, H. V. \& Klotzsch, H. (1963). Sucrose. In Methods of Enzymatic Analysis, pp. 99-IO2. Edited by H. V. Bergmeyer. New York: Academic Press.

CHeT, I. \& Mitchell, R. (1976). Ecological aspects of microbial chemotactic behaviour. Annual Review of Microbiology 30, 22 I-239.

DAHLQVIST, A. (1961). Determination of maltase and isomaltase activities with glucose oxidase reagent. Biochemical Journal 8o, 547-55I.

Hungate, R. E. (1966). The Rumen and its Microbes. New York: Academic Press.

Klotzsch, H. \& Bergmeyer, H. V. (1963). DFructose. In Methods of Enzymatic Analysis, pp. 156-I 59. Edited by H. V. Bergmeyer. New York: Academic Press.

MACHLIs, L. (1969). Zoospore chemotaxis in the water mold Allomyces. Physiologia plantarum 22, I26-I 39 .

OrPIN, C. G. (1975). Studies on the rumen flagellate Neocallimastix frontalis. Journal of General Microbiology 9r, 249-262.

OrPIN, C. G. (1977). Invasion of plant tissue in the rumen by the flagellate Neocallimastix frontalis. Journal of General Microbiology 98, 423-430.

Palleroni, N.J. (1976). Chamber for bacterial chemotaxis experiments. Applied and Environmental Microbiology 32, 729-730.

Phillipson, A. T. \& McAnally, R. A. (1942). Studies on the fate of carbohydrates in the rumen of sheep. Journal of Experimental Biology 19, 199-2I4.

Reid, C. S. W., Lyttleton, J. W. \& Mangan, J. L. (1962). Bloat in cattle. XXIV. A method for measuring the effectiveness of chewing in the release of plant cell contents from ingested feed. New Zealand Journal of Agricultural Research 5, 237-248.

Royle, D. J. \& HiCkman, C. J. (I964). Analysis of factors governing in vitro accumulation of zoospores of Pythium aphanidermatum on roots. II. Substances causing responses. Canadian Journal of Microbiology ro, 201-2 19.

WAITE, R. \& BoyD, J. (1953). The water soluble carbohydrates of grasses. I. Changes occurring during the normal life-cycle. Journal of the Science of Food and Agriculture 4, 197-204. 